\title{
Perjuangan Kesetaraan Gender Tokoh Wanita Dan Nilai Pendidikan Dalam Novel Gadis Kretek Karya Ratih Kumala
}

\author{
Maftuhah \\ Dosen Sekolah Tinggi Ilmu Tarbiyah Muhammadiyah Paciran, Indonesia \\ E-mail: kireina1704@gmail.com
}

\begin{abstract}
This study aims to describe and explain: (1) the struggle for gender equality of female characters in Ratih Kumala's novel Kretek Girl, and (2) educational values in Ratih Kumala's novel Kretek Girl. This type of research is qualitative research. This study used descriptive qualitative method. Qualitative descriptive method is a research procedure that produces description data in the form of words. The research data is a novel by Kretek Girl by Ratih Kumala.This study uses a feminism approach to describe the profile of female characters, the struggle for gender equality, and the sociological approach of literature to find out about the social conditions of the community in Ratih Kumala's novel Kretek Girl. The data collection technique used in this study was to read the entire contents of the novel and document analysis.

The results of this study are as follows: (1) The struggle for gender equality of female leaders in Ratih Kumala's novel Kretek Gadis is against forms of gender injustice in the form of (a) stereotypes, (b) marginalization of women, (c) subordination of work, and (d) internal violence household. (2) Ratih Kumala's novel Kretek Girls educational values include: (a) the value of religious education that emphasizes between humans and God, (b) the value of social education refers to the relationship of individuals to other individuals in a society (c) the value of education morals that relate to the good or bad of human behavior, and $(d)$ the value of cultural / customary education that is related to tradition, people's habits.
\end{abstract}

Keywords: Novel Kretek Girl, Gender, Educational Value

\section{Pendahuluan}

Karya sastra adalah fenomena kemanusian yang kompleks, ada peristiwa suka, duka dan berbagai peristiwa hidup lainnya. Semua itu merupakan hasil ciptaan manusia yang ditujukan untuk manusia, berisikan tentang kehidupan manusia, memberikan gambaran kehidupan dengan segala aspek kehidupannya.

Sastra adalah salah satu dari berbagai bentuk representasi budaya yang menggambarkan relasi dan rutinitas gender. Selain itu, teks sastra juga dapat memperkuat dan membuat stereotipe gender baru yang lebih merepresentasikan kebebasan gender. Oleh karena itu, kritik sastra feminis membantu membangun studi gender yang direpresentasikan dalam sastra (Goodman, 2001: p.2).

Salah satu bentuk karya sastra adalah novel. Novel adalah karya fiksi yang dibangun melalui berbagai unsur intrinsiknya. Unsur-unsur tersebut sengaja di 
padukan pengarang dan di buat mirip dengan dunia yang nyata lengkap dengan peristiwa-peristiwa didalam nya. Sehingga nampak seperti sungguh ada dan benar-benar terjadi. Dengan adanya unsur inilah yang akan menyebabkan karya sastra (novel) hadir.

Kata gender dalam istilah Bahasa Indonesia sebenarnya berasal dari bahasa Inggris yaitu 'gender'. Jika dilihat dalam kamus bahasa Inggris, tidak secara jelas dibedakan pengertian antara sex dan gender. Sering kali gender dipersamakan dengan seks (jenis kelamin laki-laki dan perempuan).

Istilah gender pertama kali diperkenalkan oleh Robert Stoller (dalam Fakih, 1999, p.8) untuk memisahkan pencirian manusia yang didasarkan pada pendefinisian yang bersifat sosial budaya dengan pendefinisian yang berasal dari ciri - ciri fisik biologis. Dalam ilmu sosial orang yang juga sangat berjasa dalam mengembangkan istilah dan pengertian gender ini adalah Ann Oakley (dalam Fakih,1999, p.71).

Suzanne Williams, Janet Seed, dan Adelina Mwau dalam The OXFAM Gender Training Manual, mengartikan gender sebagai berikut: "Manusia dilahirkan dan dididik sebagai bayi perempuan dan laki-laki supaya kelak menjadi anak perempuan dan laki-laki serta berlanjut sebagai perempuan dewasa dan lakilaki dewasa. Mereka dididik tentang bagaimana cara bersikap, berperilaku, berperan, dan melakukan pekerjaan yang sepantasnya sebagai perempuan dan laki-laki dewasa. Mereka dididik bagaimana berelasi di antara mereka, sikapsikap yang di pelajari inilah yang pada akhirnya membentuk identitas diri dan peranan gender mereka dalam masyarakat ".

Dari berbagai definisi di atas maka dapat disimpulkan bahwa gender adalah suatu konstruksi atau bentuk sosial yang sebenarnya bukan bawaan lahir sehingga dapat dibentuk atau diubah tergantung dari tempat, waktu/zaman, suku/ras/bangsa, budaya, status sosial, pemahaman agama, Negara ideologi, politik, hukum dan ekonomi. Oleh karenanya, gender bukanlah kodrat Tuhan melainkan buatan manusia yang dapat dipertukarkandan memiliki sifat relatif. Hal tersebut biasa terdapat pada laki-laki maupun pada perempuan.

Kritik sastra feminis merupakan salah satu disiplin ilmu kritik sastra yang lahir sebagai respon atas berkembangnya feminisme di berbagai penjuru dunia. Kritik sastra feminisme merupakan aliran baru dalam sosiologi sastra. Lahirnya bersamaan dengan kesadaran perempuan akan haknya. Inti tujuan kajian pendekatan feminisme adalah meningkatkan kedudukan dan derajat perempuan agar sama atau sejajar dengan kedudukan serta derajat laki-laki.

Untuk meneliti karya sastra dari aspek feminis, peneliti perlu membaca teks sebagai wanita (reading a woman) dalam istilah Culler. Membaca sebagai wanita akan lebih demokratis dan tak berpihak pada laki-laki ataupun perempuan. Dari sini peneliti, akan menemukan diegesis dan mimesis dalam teks sastra.

Berdasarkan latar belakang tersebut, maka peneliti berminat untuk menganalisis Novel Gadis Kretek, peneliti membatasi pada perjuangan kesetaraan gender tokoh wanita dan nilai pendidikan.

Alasan penulis memilih dari segi nilai pendidikan ini, karena pada novel Gadis Kretek diketahui banyak memberikan suatu inspirasi bagi pembaca khususnya. Hal itu berarti ada nilai-nilai positif yang dapat diambil dan juga dapat 
direalisasikan oleh pembaca dalam kehidupan nyata.

Berdasarkan latar belakang dan paparan di atas maka penelitian ini diberi judul "Perjuangan Kesetaraan Gender Tokoh Wanita dan Nilai Pendidikan dalam Novel Gadis Kretek Karya Ratih Kumala”

Selanjutnya dalam kajian ini permasalahan yang ingin dibahas adalah:

1. Bagaimana perjuangan kesetaraan gender tokoh wanita dalam novel Gadis Kretek Karya Ratih Kumala?

2. Bagaimanakah nilai-nilai pendidikan yang tergambar dalam novel Gadis Kretek Karya Ratih Kumala?

Tujuan dari penelitian ini adalah untuk menganalisis novel Gadis Kretek karya Ratih Kumala dengan menemukan Perjuangan kesetaraan gender tokoh wanita dan nilai-nilai pendidikan.

\section{Landasan Teori}

Kata ,gender ${ }^{\text {ee }}$ dapat diartikan sebagai perbedaan peran, fungsi, status dan tanggung jawab pada laki-laki dan perempuan sebagai hasil dari bentukan (konstruksi) sosial budaya yang tertanam lewat proses sosialisasi dari satu generasi ke generasi berikutnya. Dengan demikian gender adalah hasil kesepakatan antar manusia yang tidak bersifat kodrati. Oleh karenanya gender bervariasi dari satu tempat ke tempat lain dan dari satu waktu ke waktu berikutnya. Gender tidak bersifat kodrati, dapat berubah dan dapat dipertukarkan pada manusia satu ke manusia lainnya tergantung waktu dan budaya setempat.

Secara garis besar dijelaskannya bahwa Culler (Sugihastuti, 2005, p.5). menyebutnya sebagai reading as a woman, membaca sebagai perempuan. Yang dimaksud "membaca sebagai perempuan" adalah kesadaran pembaca bahwa ada perbedaan penting dalam jenis kelamin pada makna dan perebutan makna karya sastra. Kesadaran pembaca dalam kerangka kajian sastra feminis merupakan kajian dengan berbagai metode. Kajian ini meletakkan dasar bahwa ada gender dalam kategori analisis sastra, suatu kategori yang fundamental.

Perjuangan serta usaha feminisme untuk mencapai tujuan ini mencakup berbagai cara. Salah satu caranya adalah memperoleh hak dan peluang yang sama dengan yang dimiliki laki-laki”" (Djajanegara, 2000, p.4).

Lebih lanjut Djajanegara (2000: 27-39) menguraikan ragam kritik sastra feminis sebagai berikut:

a. KSF Ideologis, memandang wanita, khususnya kaum feminis sebagai pembaca. Yang menjadi pusat perhatian pembaca wanita adalah citra serta streotipe wanita dalam karya sastra.

b. KSF Ginokritik, mengkaji tulisan-tulisan wanita (Penulis wanita). Ginokritik mencoba mencari jawaban atas pertanyaan-pertanyaan mendasar, seperti apakah penulis-penulis wanita merupakan kelompok khusus, dan apa perbedaan antara tulisan wanita dan laki-laki.

c. KSF Sosialis (Marxis), meneliti tokoh-tokoh wanita dari sudut pandang sosialis yaitu kelas-kelas masyarakat. Pengkritik feminis mencoba mengungkapkan bahwa wanita merupakan kelas masyarakat yang tertindas.

d. KSF Psikoanalitik, diterapkan pada tulisan-tulisan wanita karena para feminis percaya bahwa pembaca wanita biasanya mengidentifikasikan 
dirinya atau menempatkan dirinya pada tokoh wanita, sedangkan tokoh wanita tersebut pada umumnya merupakan cerminan atas penciptanya.

e. KSF Lesbian, meneliti penulis dan tokoh perempuan saja. Kajian ini masih terbatas karena beberapa faktor. Pertama, para feminis pada umumnya tidak menyukai kelompok perempuan homoseksual dan memandang mereka sebagai feminis radikal. Kedua, waktu tulisantulisan tentang perempuan bermunculan pada tahun 1979-an. Jurnaljurnal perempuan tidak ada yang menulis tentang lesbianisme. Ketiga, kaum lesbian sendiri belum mampu mencapai kesepakatan tentang definisi lesbianisme. Keempat, disebabkan sikap antipati para feminis dan masyarakat, penulis lesbian terpaksa dalam bahasa yang terselubung serta menggunakan lambang-lambang, disamping menyensor sendiri.

f. KSF Etnik, mempermasalahkan diskriminasi seksual dan diskriminasi rasial dari kaum kulit putih maupun hitam, baik laki-laki maupun perempuan.

Sugihastuti (2005:15-16) mengemukakan bahwa dasar pemikiran dalam penelitian sastra berperspektif feminis adalah upaya pemahaman kedudukan dan peran perempuan seperti tercermin dalam karya sastra.

Dengan kata lain, memang ada perbedaan visi penulis laki-laki dan wanita. Kedua kubu tersebut sering memiliki daya kontra satu sama lain yang tak ada ujung pangkalnya. Bahkan kedua belah pihak sering mengungkapkan adanya sikap saling menyalahkan akibat perbedaan gender. Itulah sebabnya, analisis feminisme seyogyanya mengikuti pandangan Barret (Pradopo, 1991, p.142) yakni: (1) peneliti hendaknya mampu membedakan material sastra yang digarap penulis laki-laki dan wanita, keinginan laki-laki dan wanita, dan hal-hal apa saja yang menarik laki-laki dan wanita; (2) ideologi sering mempengaruhi hasil karya penulis. Ideologi dan keyakinan laki-laki dengan wanita tentu saja ada perbedaan yang prinsipiil; (3) seberapa jauh kodrat fiksional teks-teks sastra yang dihasilkan pengarang mampu melukiskan keadaan budaya mereka. Perbedaan gender sering mempengaruhi adat dan budaya yang terungkap. Tradisi laki-laki dan perempuan dengan sendirinya memiliki perbedaan yang harus dijelaskan dalam analisis gender.

Metode penelitian dalam kajian sastra ini hanya digambarkan secara singkat yang meliputi: metode, jenis penelitian, pendekatan (paradigma), sumber data, teknik pengumpulan data dan teknik analisis data. Sehingga penulis dapat menguraikan sebagai berikut:

\section{Metode}

Metode berasal dari Bahasa Yunani methodos yang berarti cara atau jalan yang ditempuh. Sehubungan dengan upaya ilmiah, maka metode penelitian yang digunakan dalam penelitian ini adalah metode deskriptif.

Nasir (1990:64), mengemungkakan bahwa metode deskriptif adalah suatu metode yang digunakan untuk menjelaskan kondisi suatu sistem pemikiran ataupun suatu peristiwa pada masa sekarang. Tujuan penelitian adalah untuk membuat gambaran atau lukisan secara sistematis, faktual dan akurat mengenai fakta serta hubungan antara fenomena yang diselidiki. Metode deskriptif digunakan untuk mendeskripsikan data tentang perjuangan kesetaraan gender dan 
nilai-nilai pendidikan dalam novel Gadis Kretek karya Ratih Kumala.

\section{Jenis penelitian}

Jenis penelitian ini adalah penelitian kualitatif. Penelitian ini menggunakan metode deskriptif kualitatif. Metode deskriptif kualitatif adalah prosedur penelitian yang menghasilkan data deskripsi berupa kata-kata. Data penelitian ini adalah novel Gadis Kretek karya Ratih Kumala.

\section{Pendekatan (Paradigma)}

Penelitian ini menggunakan pendekatan feminisme untuk mendeskripsikan profil tokoh wanita, perjuangan kesetaraan gender, dan pendekatan sosiologi sastra untuk mengetahui nilai religius, nilai sosial, nilai moral dan nilai budaya dalam novel Gadis Kretek karya Ratih Kumala.

\section{Sumber Data}

Sumber data dalam penelitian ini adalah novel Gadis Kretek karya Ratih Kumala. Data yang dimaksudkan merupakan kutipan-kutipan yang berhubungan dengan perjuangan kesetaraan gender tokoh wanita dan nilai-nilai pendidikan di dalam karya tersebut. Novel tersebut diterbitkan pada bulan Maret 2012, dengan jumlah halaman 274, dan diterbitkan oleh PT Gramedia Pustaka Utama. Hasil penelitian ini menunjukkan bahwa Novel Gadis Kretek karya Ratih Kumala mengandung nilai-nilai pendidikan karakter. Nilai pendidikan karakter yang ditemukan dalam novel Gadis Kretek di antaranya yaitu jujur, toleransi, kerja keras, percaya diri, kreatif, mandiri, tanggung jawab, cinta tanah air, menghargai prestasi, bersahabat, gemar membaca, dan peduli sosial. Nilai pendidikan karakter yang ditemukan adalah karakter jujur dan cinta tanah air.

\section{Teknik Pengumpulan Data}

Teknik pengumpulan data di dalam penelitian ini mengikuti prosedur sebagai berikut:

1) Teknik Observasi

Teknik observasi dilakukan dengan cara membaca seluruh isi novel secara cermat dan teliti.

2) Teknik Dokumentasi

Teknik dokumentasi dilakukan dengan cara mencatat kata-kata, kalimat, dan dialog dalam novel yang berkaitan dengan permasalahan yang diteliti.

\section{Teknik Analisis Data}

Adapun langkah-langkah analisis datanya sebagai berikut:

1. Membaca novel Gadis Kretek karya Ratih Kumala secara cermat dan teliti.

2. Mencatat kalimat yang menggambarkan perjuangan kesetaraan gender dan nilai pendidikan dalam novel Gadis Kretek karya Ratih Kumala.

3. Menganalisis perjuangan kesetaraan gender tokoh wanita dan nilai pendidikan dalam novel Gadis Kretek karya Ratih Kumala.

\section{Pembahasan}

Novel karya Ratih Kumala ini bercerita tentang kisah cinta dalam keluarga pemilik bisnis rokok kretek. Novel ini memiliki alur waktu bolak balik, antara zaman modern ini dan era penjajahan tahun 1930-1950 an. Bahasa dalam novel ini cukup mudah dimengerti, tidak menggunakan kosakata sulit ataupun kalimat yang 
"berat". Novel ini dapat dijadikan bacaan yang menyenangkan di akhir minggu, atau menemani sore yang menarik, sebagai kelengkapan kisah cinta, novel ini pun mengisahkan sejarah pendirian industri kretek kala itu. Tokoh utama dalam novel ini bertugas menelusuri sejarah masa lalu keluarganya untuk menemukan sesosok Jeng Yah.

Sementara, hal lain yang sangat menarik adalah mengenai semangat feminisme yang kental. Hal pertama yang menarik peneliti untuk membaca buku ini adalah bagian covernya yang menarik. Digambarkan seorang perempuan berkebaya, sedang merokok kretek. Judul bukunya pun "Gadis Kretek".

1. Bentuk ketidakadilan gender yang ada dalam novel "Gadis Kretek" karya Ratih Kumala, meliputi: stereotipe, marginalisasi, subordinasi, dan kekerasan.

a. Stereotipe adalah suatu pelabelan atau penandaan yang sering kali bersifat negatif secara umum terhadap salah satu jenis kelamin tertentu. Stereotipe selalu melahirkan ketidakadilan dan diskriminasi yang bersumber dari pandangan gender.

b. Marginalisasi adalah proses, sikap, perilaku masyarakat maupun kebijakan negara yang berakibat pada penyisihan atau kemiskinan bagi perempuan atau laki-laki.

c. Subordinasi adalah suatu keyakinan bahwa salah satu jenis kelamin dianggap lebih penting atau lebih utama dibandingkan jenis kelamin lainnya, sehingga ada jenis kelamin yang merasa dinomorduakan atau kurang didengarkan suaranya, bahkan cenderung dieksploitasi tenaganya.

d. Kekerasan adalah suatu serangan terhadap fisik maupun integritas mental psikologi seseorang.

2. Nilai-nilai Pendidikan yang ada dalam novel "Gadis Kretek" karya Ratih Kumala, meliputi: nilai religius, nilai sosial, nilai moral dan nilai budaya.

a. Nilai Religius yaitu bertaqwa kepada Tuhan Yang Maha Esa, menjalankan perintah-Nya dan meninggalkan segala larangan-Nya.

b. Nilai sosial yaitu toleransi, prasangka baik, membela kaum yang tertindas, sopan santun dalam tindak tutur, dan suka menolong.

c. Nilai moral yaitu hormat kepada orang tua, tidak menganggap segalanya dapat digantikan dengan harta benda, menghormati dan sopan santun pada orang yang lebih tua, dan memerangi kemungkaran.

d. Nilai budaya yaitu sesuatu yang dianggap baik dan berharga oleh suatu kelompok masyarakat atau suku bangsa yang belum tentu Kesimpulan dipandang baik pula oleh kelompok masyarakat atau suku bangsa lain.

1. Bentuk ketidakadilan gender dalam novel "Gadis Kretek" karya Ratih Kumala, meliputi: bentuk stereotipe, marginalisasi, subordinasi, dan kekerasan.

2. Nilai-nilai pendidikan dalam novel "Gadis Kretek" karya Ratih Kumala, meliputi: nilai religius, moral, sosial dan budaya. 


\section{Saran}

Dapat memberikan pengetahuan dan pengalaman dalam dunia pendidikan, khususnya dalam bidang Pendidikan Bahasa dan Sastra Indonesia.

\section{Daftar Rujukan}

Culler, Jonathan. 1983. On Deconstrutction: Theory and Criticism after Structuralism. London and Henley: Routledge and Kegan Paul.

Chamamah-Soeratno, 1988, Hikayat Iskandar Zulkarnain: Suntingan Teks dan Analisis Resepsi. Disertai, Universitas Gajah Mada, Yogyakarya.

Fakih, Mansour, 1999 (1996), Analisis Gender Dan Transformasi Sosial, Yogyakarta: Pustaka Pelajar.

Kutha Ratna, Nyoman. Teori, Metode dan Teknik Penelitian Sastra. Yogyakarta: Pustaka Pelajar, 2007.

Lips, Hilary M. (1993). Sex and Gender: An Introduction. London: Myfield Publishing Company.

Megawangi, Ratna (1999). Membiarkan Berbeda: Sudut Pandang Baru tentang Relasi Gender. Bandung: Mizan. Cet. I.

Nurgiyantoro, Burhan. 2005. Teori Pengkajian Fiksi. Yogyakarta: Gajah Mada University Press.

Oxfam, "Gender Development Organizations", Gender And Development Vol 5 /February 1997.

Showalter, Elaine, 1985, The New Feminist Criticism, New York: Pantheon Book.

Selden, Raman. 1991. Panduan Pembaca Teori Sastra Masa Kini (diterjemahkan oleh Rachmat Djoko Pradopo). Yogyakarta. Gajah Mada University Press.

Showalter, Elaine, 1988, "Feminist Criticism in the Wilderness" dalam David Lodge Modern Criticism and Theory. London and New York: Longman.

Sugihastuti. 2002. Teori dan Apresiasi Sastra. Yogyakarta: Pustaka Pelajar.

Umar, Nasruddin, 1999, Argumen Kesetaraan Gender, Jakarta: Paramadina.

Yoder, Linda, 1986, "Creating the Critical Quilt; The Shared Task of Feminist Criticism", makalah: tidak diterbitkan.

www.gramediapustakautama.com

http://sepetaklangitku.blogspot.com/2012/04/gadis-kretek.html

Twitter : http: // www. Twitter.com/ratih kumala

Website: http: // ratih kumala.com 
Maftuhah

62 Annaba: Jurnal Pendidikan Islam 